\title{
Uji Fitokimia Ekstrak Metanol Sargassum polycystum dari perairan Pulau Lemukutan Kalimantan Barat
}

\author{
Sukal Minarti ${ }^{1 *}$, Nora Idiawati ${ }^{1}$, Mega Sari Juane Sofiana ${ }^{1}$ \\ 1 Program Studi Ilmu Kelautan, FMIPA, Universitas Tanjunpura, Pontianak- \\ Indonesia \\ *Correspondence email: Sukal Minarti \\ $\underline{\text { sukalminarti02@gmail.com }}$
}

\author{
Received : 06 February 2019 - Accepted: 22 March 2019 \\ Published: 30 June 2019 @ Author(s) 2019. This article is open access
}

\begin{abstract}
Makroalga adalah tumbuhan laut yang hidup di perairan. Makroalga termasuk dalam spesies multiselular menyerupai akar, batang dan daun. Sargassum polycystum merupakan spesies makroalga coklat (Phaeophyceae) yang khas dari perairan pulau Lemukutan, Kalimantan Barat. $S$. polycytum ini memiliki senyawa-senyawa metabolit sekunder yang berpotensi sebagai senyawa bioaktif, seperti antibiotik. Metabolit sekunder berfungsi untuk mempertahankan diri dari kondisi lingkungan yang kurang menguntungkan. Oleh karena itu S. polycystum dapat dijadikan sebagai sumber senyawa penghasil antibiotik. Penelitian ini bertujuan untuk mengidentifikasi golongan senyawa metabolit sekunder pada ekstrak S. polycytum. Ekstraksi dilakukan dengan metode maserasi dengan menggunakan pelarut metanol. Uji fitokimia dilakukan untuk mengetahui golongan senyawa metabolit sekunder yang terdapat pada makroalga $S$. polycystum seperti alkaloid, flavonoid, steroid, tanin dan saponin. Hasil uji fitokimia pada ekstrak $S$. polycystum adalah alkaloid, saponin dan tanin.
\end{abstract}

Keywords: Sargassum polycytum, metabolit sekunder, uji fitokimia, dan Lemukutan.

\section{Pendahuluan}

Makroalga merupakan tumbuhan yang mendominasi semua perairan di dunia. Makroalga dibagi menjadi tiga tipe bedasarkan pigmennya, yaitu Chlorophycae (alga hijau), Rhodophyceae (alga merah), dan Phaeophyceae (alga coklat), (Kadi, 2005). Salah satu golongan makroalga coklat Phaeophyceae yaitu Sargassum polycystum (Jannah et al., 2014). Makroalga berperan sebagai produsen primer dan habitat bagi biota (Baleta et al., 2017).
Makroalga menghasilkan metabolit sekunder sebagai bentuk pertahanan diri (Aguilera et al., 2002). Metabolit sekunder yang dihasilkan oleh makroalga memiliki berbagai bioaktivitas seperti antioksidan (Sanger et al., 2013), antijamur (Oumaskour et al., 2012), dan antibakteri (Salem et al., 2011; Hutner et al., 2013).Kandungan metabolit sekunder yang ada pada makroalga adalah flavonoid, steroid, phenol, tanin, dan terpenoid (Baleta et al., 2017).

Penelitian uji fitokimia pada makroalga cokelat telah banyak dilakukan. Ekstrak 
metanol S. polycystum dari Pulau Panjang, Jepara memiliki senyawa metabolit sekunder steroid dan triterpenoid (Riyanto et al., 2013). Ekstrak metanol S. vulgare dari pantai Kapong, Pamekasan, Madura memiliki senyawa metabolit sekunder steroid (Jannah et al., 2014). Ekstrak metanol S.duplicatum dari pantai Ranca Babakan, Nusakambangan, Cilacap memiliki senyawa metabolit sekunder flavonoid, tanin, saponin dan terpenoid (Septiana et al., 2012).

Makroalga cokelat di pulau Lemukutan Kalimantan Barat didominasi oleh $S$. polycytum. Namun kandungan senyawa metabolit sekunder dimakroalga tersebut belum diketahui. Oleh karena itu, penelitian ini bertujuan untuk mengetahui metabolit sekunder dari ekstrak metanol S. polycytum dari perairan Pulau Lemukutan, Kalimantan Barat.

\section{Metode}

2.1 Parameter Fisikia-Kimia Lingkungan Pengambilan sampel pertama dilakukan pada tanggal 24 Mei 2017 dan pengambilan sampel kedua dilakukan pada tanggal $21 \mathrm{Juli}$ 2019. Pengambilan sampel makroalga $S$. polycystum dilakukan di perairan Pulau Lemukutan, Kabupaten Bengkayang, Kalimantan Barat. Lokasi pengambilan sampel terdapat di Teluk Melano bagian Barat pada titik koordinat $0^{\circ} 45^{\prime} 33,84^{\prime \prime} \mathrm{LU}$ $108^{\circ} 42^{\prime} 32,65^{\prime \prime}$ BT, Teluk Melano bagian Timur pada titik koordinat $0^{\circ} 44^{\prime} 35,18^{\prime \prime} \mathrm{LU}$ - $108^{\circ} 42^{\prime} 51,79^{\prime \prime}$ BT, dan di Teluk Cina bagian Selatan pada titik koordinat $0^{\circ} 46^{\prime} 56,47^{\prime \prime} \mathrm{LU}$ $108^{\circ} 42^{\prime} 25,56^{\prime \prime}$ BT (Gambar 1). Penelitian uji fitokimia dilakukan di Laboratorium Riset dan Bioteknologi, Fakultas Matematika dan Ilmu Pengetahuan Alam, Universitas Tanjungpura.

\subsection{Prosedur Penelitian \\ 2.2.1 Parameter Fisikia-Kimia Lingkungan}

Sampel makroalga diambil sebanyak $20 \mathrm{~kg}$ dari perairan Pulau Lemukutan. Sampel selanjutnya dicuci dandikeringkan. Sampel kering kemudian dihaluskan dan diekstraksi.

\subsubsection{Ekstraksi}

Sampel yang telah dihaluskan, ditimbang sebanyak 500 g. Sampel dimaserasi menggunakan pelarut metanol. Maserasi dilakukan selama 2 x 24 jam. Hasil maserasi dievaporasi sehingga diperoleh ekstrak metanol.

\subsubsection{Uji Fitokimia}

Uji fitokimia dilakukan untuk mengetahui golongan senyawa metabolit sekunder yang terdapat pada makroalga $S$. polycystum dari perairan Pulau Lemukutan.Uji fitokimia yang dilakukan menggunakan metode dariHarborne, (1987) meliputi :

1) Alkaloid

Ekstrak S. polycystum sebanyak $0,05 \mathrm{mg}$ dilarutkan dalam 5 tetes $\mathrm{HCl}$. Uji ini

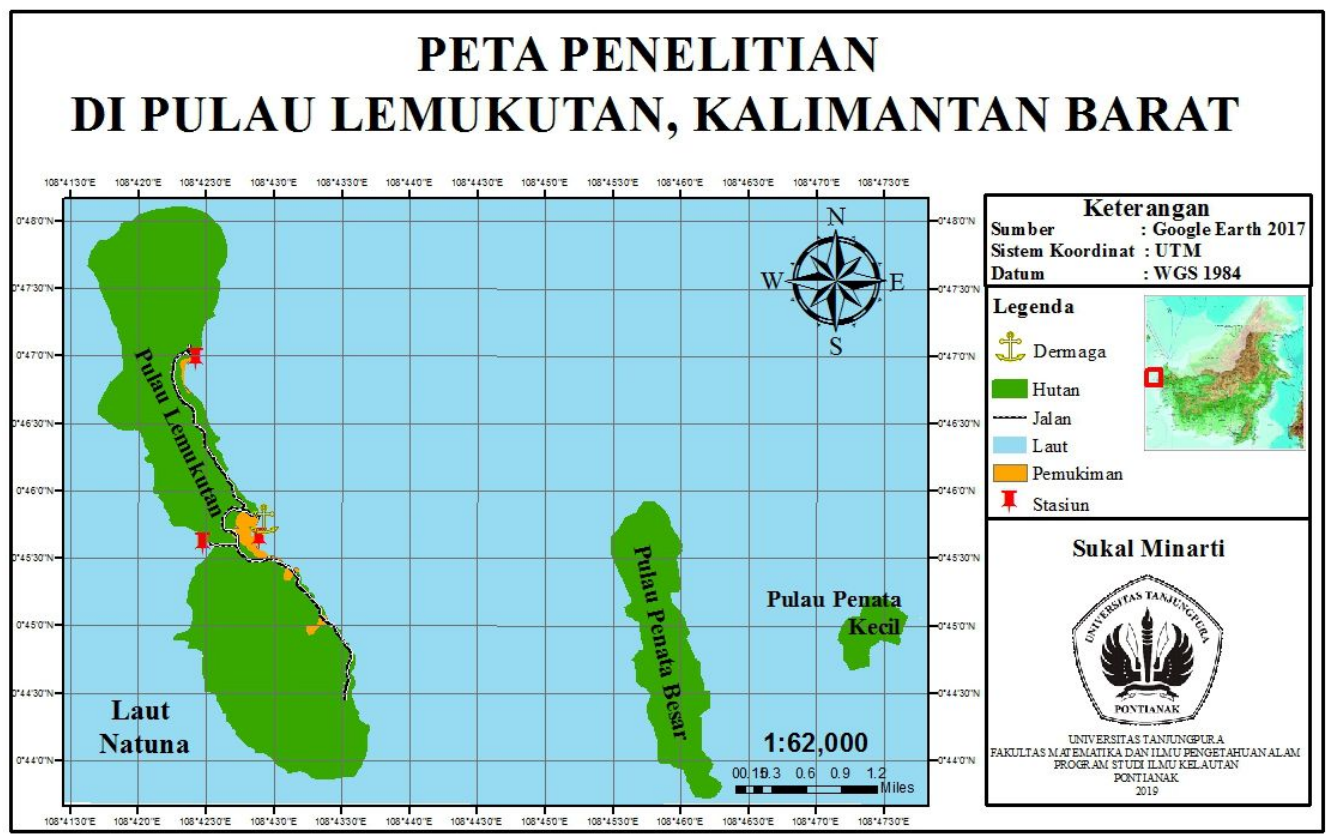

Gambar 1. Peta lokasi pengambilan data 


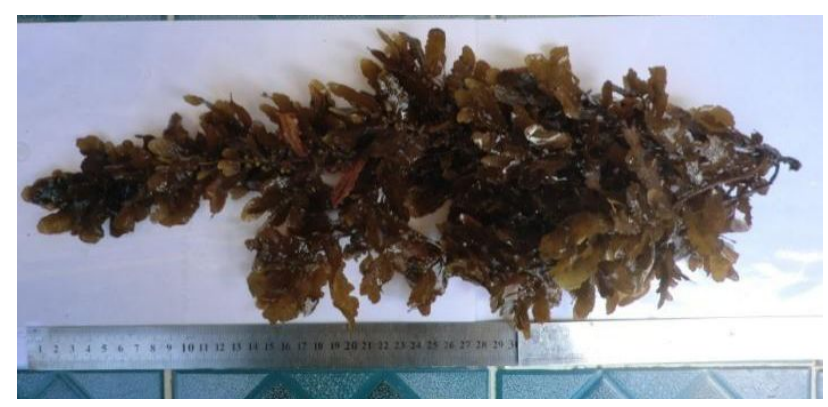

Gambar 2. Sampel S. polycystum

dilakukan dengan menggunakan pereaksi tiga pereaksi seperti, Dragendorff, Meyer dan Wagner. Hasil uji dinyatakan positif jika Meyer terbentuk endapan putih, endapan cokelat dengan Wagner dan endapan jingga dengan pereaksi Dragendorff.

2) Steroid

Ekstrak $S$. polycystum sebanyak $0,05 \mathrm{mg}$ dilarutkan dalam 10 tetes anhidrat asetat dan 3 tetes asam sulfat pekat. Hasil uji positif ditujukkan dengan berubahnya warna larutan merah menjadi biru.

3) Flavonoid

Ekstrak S. polycystum sebanyak $0,05 \mathrm{mg}$ dimasukkan ke dalam tabung reaksi kemudian dilarutkan dalam 1-2 mL metanol. Sampel ditambahkan serbuk magnesium 0,1 $\mathrm{mg}$ dan 3 tetes $\mathrm{HCl}$ pekat. Hasil positif ditunjukkan dengan berubahnya warna larutan merah atau jingga.

4) Saponin

Ekstrak $S$. polycystum sebanyak $0,05 \mathrm{mg}$ dimasukkan dalam tabung reaksi yang berisi akuades $5 \mathrm{~mL}$. Selanjutnya ekstrak ditambahkan 1 tetes $\mathrm{HCl}$. Hasil positif ditujukan dengan terbentuknya busa.

5) Tanin

Ekstrak $S$. polycystum sebanyak $0,05 \mathrm{mg}$ ditambah akuades. Ekstrak selanjutnya didihkan dan disaring. Filtrat yang diperoleh ditambahkan. Hasil positif ditunjukkan dengan berubahnya larutan menjadi hijaukehitaman.

\section{Hasil dan Pembahasan}

\subsection{Ekstrak Sampel S. polycystum}

Sampel makroalga $S$. polycystum diambil dari perairan Pulau Lemukutan Kalimantan Barat (Gambar 2). Sampel makroalga coklat yang ditemukan termasuk dalam spesies Sargassum polycystum. Sampel makroalga $S$. polycystum yang berasal dari pulau Lemukutan memiliki morfologi yaituthalus yang bewarna cokelat,bentuk daun lebar, bergerigi seperti duri-duri kecil disetiap ujung daun, holdfast membentuk cakram kecil, batang pendek dan panjang dengan percabangan utama tumbuh rimbun, mempunyai gelembung udara (bladder) berbentuk bulat. Makroalga S. polycystum diambil pada kedalaman 0,5 hingga 2,5 m.Parameter yang dapat mempengaruhi pertumbuhan S. polycystum di perairan Pulau Lemukutan antara lain seperti temperatur sebesar $34^{\circ} \mathrm{C}$, salinitas $27,5 \%$, dan $\mathrm{pH} 8$. Kondisi perairan yang baik untuk makroalga memiliki suhu berkisar antara $31-35^{\circ} \mathrm{C}$, salinitas 29-30 \%o, dan $\mathrm{pH}$ air 7-8 (Widyartini et al., 2012). Kondisi lingkungan ini merupakan kondisi perairan yang cocok untuk pertumbuhan makroalga coklat seperti S. polycystum.

Tabel 1. Hasil Uji Fitokimia pada Ekstrak Sargassum polycystum

\begin{tabular}{cccc}
\hline \hline Uji fitokimia & Pereaksi & Ekstrak Metanol & Keterangan \\
\hline Alkaloid & Mayer & + & Endapan Putih \\
& Wagner & + & Endapan Coklat \\
& Dragendroff & + & Endapan Jingga \\
Flavonoid & $\mathrm{Mg}+\mathrm{HCl}$ pekat & - & Merah atau Jingga \\
Saponin & Air $+\mathrm{HCl}$ & + & Busa \\
Steroid & Anhidrat Asetat & - & Hijau \\
& $\mathrm{H}_{2} \mathrm{SO}_{4}$ & - & Hijau \\
Tannin & $\mathrm{FECl}_{3}$ & + &
\end{tabular}

Keterangan: hasil uji negatif ( - ); hasil uji positif (+) 


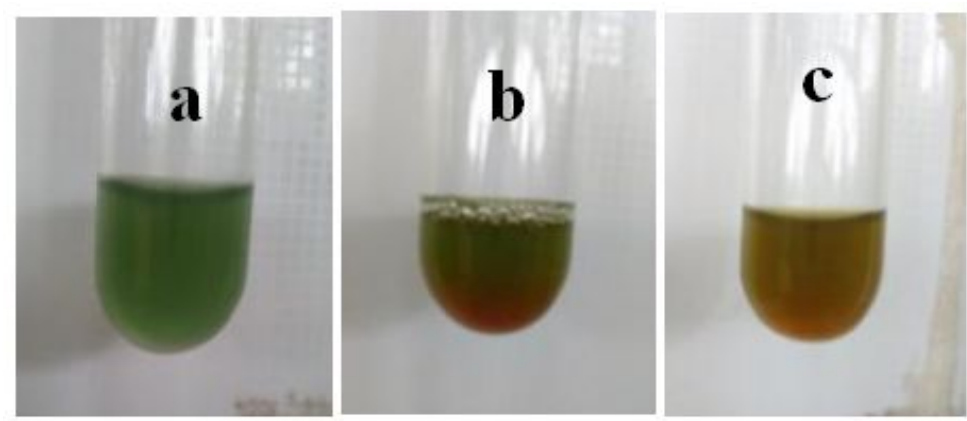

Gambar 3. Hasil uji alkaloid a) Mayer; b) Dragendroff; c) Wagner

Hasil ekstrak metanol pada $S$. polycystum yang diperoleh adalah $13,93 \mathrm{~g}$. Pada proses maserasi, ekstrak metanol berbentuk pasta kental (hijau kecoklatan). Hasil menunjukkan bahwa kadar metabolit sekunder yang bersifat polar (metanol) banyak terdapat dalam sampel S. polycystum karena banyaknya ekstrak sampel dari pelarut metanol yang dihasilkan. Berdasarkan hasil yang didapatkan dinyatakan bahwa $S$. polycystum mengandung metabolit sekunder yang relatif larut dalam pelarut polar.

\subsection{Fitokimia}

Uji fitokimia menunjukkan setiap ekstrak yang terdapat pada senyawa metabolit mendapatkan hasil warna yang berbeda-beda, dapat dilihat pada (Tabel 1). Hasil penelitian uji metabolit sekunder pada ekstrak metanol Sargassum polycystum menunjukkan hasil positif yang terdapat pada golongan metabolit sekunder seperti: alkaloid, saponin dan tanin. Berdasarkan penelitian Riyanto et al. (2013) dengan hasil uji fitokimia pada makroalga coklat $S$. polycystum pada ekstrak metanol dari Pulau Panjang, Jepara memiliki senyawa metabolit sekunder steroid dan triterpenoid. Hasil uji fitokimia pada makro alga $S$. vulgare pada ekstrak metanol memiliki senyawa metabolit sekunder steroid dari pantai Kapong, Pamekasan, Madura (Jannah et al., 2014). Ekstrak metanol S.duplicatum memiliki senyawa metabolit sekunder flavonoid, tanin, saponin dan terpenoiddari pantai Ranca Babakan, Nusakambangan, Cilacap (Septiana et al., 2012).

Hasil uji alkaloid pada ekstrak metanol $S$. polycystum ditujukkan dengan terbentuknya endapan putih, coklat dan jingga (Gambar 3). Endapan ini bewarna coklat muda yang dihasilkan oleh kalium alkaloid. Nitrogen pada uji alkaloiddengan pereaksi Dragendorff membentuk ikatan kovalen koordinat dengan $\mathrm{K}+$ yang merupakan ionlogam (Marliana, 2005). Pada pembuatan pereaksi Wagner, iodin bereaksi dengan ion I dari kalium iodide (KI) menghasilkan I3-yang bewarna coklat. Pada uji Wagner, ion logam $\mathrm{K}+$ akan membentuk ikatan kovalen koordinat dengan nitrogen pada alkaloid membentuk kalium alkaloid yang mengendap.

Hasil senyawa flavonoid pada ekstrak metanol $S$. polycystum menunjukkan hasil negatif dengan terbentuknya warna putih (Gambar 4a). Flavonoid biasanya terdapat pada tumbuhan tingkat tinggi. S. polycystum merupakan tumbuhan tingkat rendah (Kemer et al., 2015). Senyawa flavonoid pada tumbuhan berfungsi sebagai pertahanan
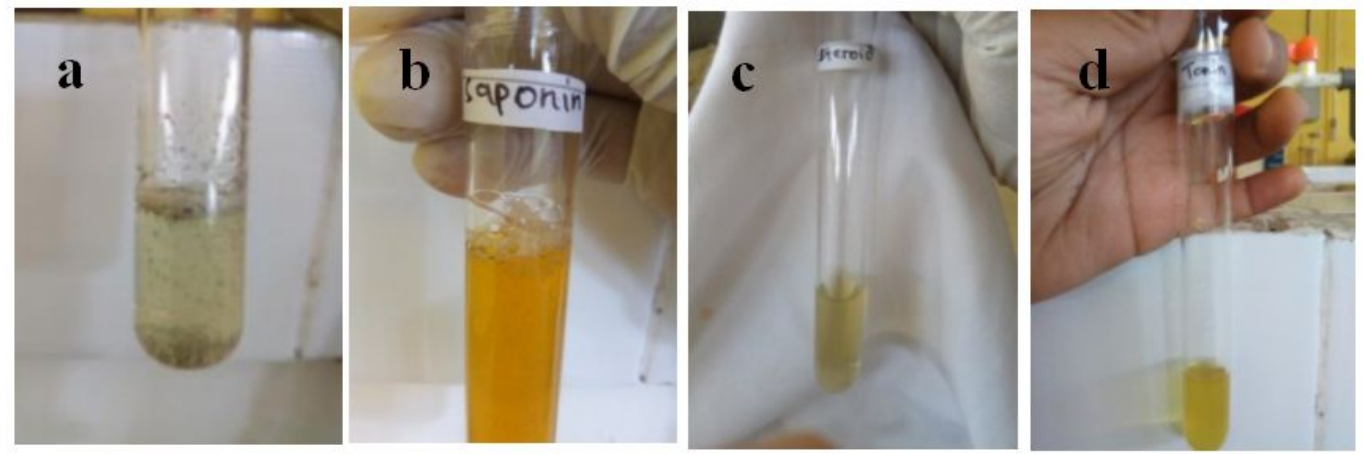

Gambar 4. Hasil uji a) Flavonoid; b) Saponin; c) Steroid; d) Tanin 
terhadap lingkungan yang bersifat suboptimal (Khotimah et al., 2013). Flavonoid dinyatakan positif, apabila pengujian serbukekstrak menggunakan $\mathrm{HCl}$ pekat dan potongan pita magnesium akan memberikan jingga (Nugrahani et al., 2016).

Hasil senyawa saponin pada ekstrak metanol $S$. polycystum menunjukkan hasil positif dengan terbentuknya busa (Gambar 4b). Hal tersebut dikarenakansaponin mudah larut pada pelarut metanol .Busa pada larutan yang terbentuk menunjukkanadanya glikosida yang terhidrolisis menjadi glukosa dansenyawa lainnya (Nugrahani et al.,2016). Ekstrak saponinakan lebih banyak dihasilkan jika diekstraksi menggunakanmetanol karena saponin bersifat polar sehingga akan lebihmudah larut daripada pelarut lain (Suharto et al., 2012).

Hasil senyawa steroid pada ekstrak metanol S. polycystummenunjuk pada hasil negatif dengan terbentuknyawarna putih (Gambar 4c). Senyawa steroid akan mengalami dehidrasi dengan penambahan asam kuat (H2SO4) pekat, yang membentuk garam yang memberikan sejumlah reaksi warna (Mukhlis, 2010).

Hasil senyawa tanin pada ekstrak $S$. polycystum menunjukkan hasil positif dengan terbentuknya warna hijau (Gambar 4d). Tanin terdapat dalam tumbuhan berpembuluh (vaskuler), angiospermae, dan jaringan kayu. Tanin dapat bereaksi dengan protein membentuk kopolimer yang tidak dapat larut dalam air (Harborne, 1987).

\section{Kesimpulan}

Berdasarkan penelitian dapat disimpulkan bahwa ekstrak metanol $S$. polycystum mengandung senyawa golongan alkaloid, saponin, dan tanin. Sedangkan flavonoid dan steroid tidak ditemukan pada ekstrak metanol S. polycystum.

\section{Daftar Pustaka}

Aguilera, J.,Bischof, K.;Karsten, U.;Hanelt, D. and Wiencke, C. 2002.Seasonal variation in ecophysiological patterns in macroalgaefrom an Arctic fjord. II. Pigment accumulation and biochemicaldefence systems against high light stress.J. of Marine biology.140:1087-1095.

Baleta, N.F., Bolaños, M.J.; Ruma, C.O.; Baleta, N.A. and Cairel, D.J. 2017. Phytochemicals screening and antimicrobial properties of Sargassum oligocystum and Sargassum crassifolium Extracts.J. of Medicinal Plants Studies.5:382-387.
Harborne, J. B. 1987.Metode Fitokimia Penuntun Cara Modern Menganalisis Tumbuhan. Bandung: ITB.

Huttner, A.,Harbarth, S.;Carlet, J.; Cosgrove, S.;Goossens, H.; Holmes, A.; Jarlier, V. and Voss, A. 2013.Antimicrobial resistance: a global view from the 2013 World Healthcare-Associated

InfectionsForum.J.ofAntimicrobial Resistance and Infection Control.2:1-13

Jannah, M., Hanapi, A. dan Fasya, G.A. 2014.Uji Toksisitas Dan Fitokimia Ekstrak Kasar Metanol, Kloroform Dan N-Heksana Alga Coklat Sargassum Vulgare Dari Pantai Kapong Pamekasan Madura.J. ALCHEMY.3:194-203.

Khotimah, K., Darius.dan Sasmito,B.B. 2013. Uji Aktivitas Senyawa Aktif Alga Coklat (Sargassum fillipendulla) Sebagai Antioksidan Pada Minyak Ikan Lemuru (Sardinella longiceps).J. THPi Student.1:10-20.

Marliana, S.D., Suryanti,V. dan Suyono.2005. Skrining Fitokimia dan Analisis Kromatografi Lapis Tipis Komponen Kimia Buah Labu Siam(Sechium edule Jacq.Swartz.)dalam Ekstrak Etanol.J. Biofarmasi.3:26-31.

Mukhlis, 2010.Ekstraksi Zat Warna Alami dari Kulit Batang Jamblang (Syzygiumcumini) sebagai Badan dasar Pewarna Tekstil.Banda Aceh, FKIP Unsyiah Darussalam (Skripsi).

Nugrahani, R., Andayani, Y.dan Hakim A. 2016.Skrining Fitokimia Dari Ekstrak Buah Buncis (Phaseolus Vulgaris L)Dalam Sediaan Serbuk.J. PPIPA. 2: 93-103.

Kadi A., 2005, Beberapa Catatan Kehadiran Marga Sargassum Diperairan Indonesia. J. of Ocean Indonesian. 30:19-29.

Oumaskour, K., Boujaber, N.,Etahiri, S. and Assobhei, O. 2012.Screening of antibacterial and antifungal activities in green and brown algae from the coast of Sidi Bouzid (El Jadida, Morocco).African Journal of Biotechnology. 11:16831-16837.

Renhoran. M. 2012.Aktivitas Antioksidan Dan Antimikroba Ekstrak Sargassum polycystum. Bogor. IPB.Fakultas Perikanan Dan Ilmu Kelautan (Skripsi).

Riyanto, I.E.,Widowati, I. dan Sabdono, A. 2013.Skrining Aktivitas Antibakteri Pada Ekstrak Sargassum polycystumTerhadap Bakteri Vibrio Harveyi dan Micrococcus Luteus Di Pulau PanjangJepara.J.of Marine Research. 1:155-121.

Sanger, G., Widjanarko, B.S., Kusnadi, J. and Berhimpon, S. 2013.Antioxidant Activity of Metanol Extract of Sea WeedsObtained from North Sulawesi.J. Food Science and Quality Management. 9:63-70.

Salem, W.M., Galal, H. and Nasr El-deen, F. 2011.Screening for antibacterial activities in some marine algae from the red sea.J. of Microbiology Research. 5:2160-2167. 
Septiana, T.A andAsnani, A. 2012. Kajian Sifat Fitokimia Ekstrak Rumput Laut Cokelat Sargassum duplicatum Menggunakan Berbagai Pelarut dan Metode Ekstraksi.J. AGROINTEK. 6: 22-28.

Suharto, M.A.P,Edy, J.H. dan Dumanauw, M.J. 2012. Isolasi dan Identifikasi SenyawaSaponin Dari Ekstrak Metanol Batang Pisang Ambon(Mussa paradisiaca var. sapientum L).J.Pharmacon. 1:86-92.

Sutriani, 2011.Uji Fitokimia dan Aktivitas Antioksidan dari Ekstrak Kangkung Air (Ipomoea aquatica Forsk).Manado.Universitas Sam Ratulangi (skripsi).

Widyartini, S.D., Widodo, P. and Susanto, B.A. 2017.Thallus variation of Sargassum polycystum from Central Java, Indonesia.J. of Biodirversitas.18:1004-1011. 